\title{
Determination of the Early Ripeness of Potato Variety Samples by the Concentration of Cell Sap of Etiolated Tubers Sprout
}

\section{T.E.Ostonakulov}

\begin{abstract}
The article presents the results of a comparative study of the concentration of cell sap in potato seedlings when evaluating for early ripeness with the methods of phenological observations and test digging of bushes.
\end{abstract}

Keywords : Variety samples, cell sap concentration of tuber sprouts, early ripeness, vegetation period, phenological observations, test digging of bushes, coefficient of adaptability.

\section{INTRODUCTION}

According to the International Classification, the early ripeness of potato varieties is divided into five groups: early with a vegetation period of 71-80 days (estimated at 3 points), medium-early, the vegetation period of which lasts 81-90 days (4 points); middle ripening, with a vegetation period of 91-110 days (5 points); middle-late with a vegetation period of 111-120 days (6 points), late ripeness, the vegetation period of which is 121-140 days or more (7-9 points).

We found that in our irrigated conditions the cultivation of early and mid-early varieties of potatoes have several advantages [T. E. Ostonakulov et al., 2017, 2018]:

- for a short period of time, spending less expenditure of funds and labor, provide high and high-quality crops, as well as the cultivation of other repeated crops (vegetables, melons and gourds, fodder, etc.);

- rational use of irrigated land, water, machinery, fertilizers and labor resources;

- only at the expense of early and mid-early varieties of potatoes it is possible to cultivate them as an early, repetitive, double-crop;

- Seed production issues are resolved;

-the industry becomes profitable.

Early ripeness of a potato variety is determined by its ability to produce a high yield of tubers in the early stages. This ability of a variety depends on the time of onset of tuber formation and the intensity of their mass accumulation. The earlier this or that variety is able to accumulate the harvest of commercial tubers, the earlier it is ripe, the higher it's economic value (B.A. Pisarev, 1977).

For early ripeness, potatoes are assessed by test digging (Research Methodology on potato culture, 1967). Estimates of early ripeness of a variety can be made from the structure

Revised Manuscript Received on July 22, 2019.

T.E.Ostonakulov, Doctor of Agricultural Sciences, Professor,Samarkand Institute of Veterinary Medicine(SamIVM)e-mail: t-ostonakulov@mail.ru of the bush, the morphological features of the potato sprouts, the depth of the root system, etc.

To assess the potato on the basis of early ripeness, it is possible to use physiological indicators (higher intensity of transpiration and assimilation due to the presence of wide and slowly closing stomatal crevices, etc., N.S. Batsanov, 1970).

As can be seen from the above, the assessment and selection of variety samples at an early stage of selective work does not allow selecting the necessary early-ripening forms due to laboriousness and duration (the method of test digging, phenological observations).

Therefore, the identification of an accelerated field rapid method for determining the early maturity of variety samples or breeding material in the early stages of work is highly relevant.

\section{MATERIALS AND METHODS}

The object of the study was 70 potato variety samples, differing in early ripeness. Each variety sample was planted with 100 tubers on March 5-8 according to a 70 × $20 \mathrm{~cm}$ planting scheme with $6-8 \mathrm{~cm}$ embedding.

During the vegetation period of the plants, phenological observations were made, with the dates of the onset of the onset $(10 \%)$ and mass $(75 \%)$ of seedlings, budding, flowering, yellowing and dying of the foliage. Then, the duration of the interphase periods and the vegetation period of the studied variety samples was determined. During the vegetation period of plants on 55th, 65th and 75th days after germination, the intensity of the accumulation of tubers was determined by the method of test digging of bushes (10 bushes from each variety sample) (Research Methodology on potato culture,All-Russian Scientific Research Institute of Potato Farming, 1967).

Before planting in the spring in the process of germination of seed tubers in potato variety samples, we determined the concentration of sprouts cell sap. For this, the upper part of the sprouts 4-6 cm long was taken, crushed, the resulting juice was immediately determined by the concentration of the accelerated field method using a Pocket Pal-1 refractometer, manufactured in Japan.

\section{DISCUSSION OF RESEARCH RESULTS}

The results of the study of assessing the early ripeness of potato variety samples by 
Determination of the Early Ripeness of Potato Variety Samples by the Concentration of Cell Sap of Etiolated Tubers Sprout

phenological observations, test digging of bushes (yield accumulation intensity), as well as the concentration of cell sap of etiolated sprouts are shown in Table 1.

Evaluation of precocity varieties of potatoes

(2014-2018)

\begin{tabular}{|c|c|c|c|c|c|c|c|}
\hline \multirow[t]{2}{*}{ № } & \multirow[t]{2}{*}{$\begin{array}{l}\text { Name and origin of } \\
\text { variety samples }\end{array}$} & \multirow[t]{2}{*}{$\begin{array}{c}\text { Vegetationperiod } \\
\text {, indays }\end{array}$} & \multicolumn{3}{|c|}{$\begin{array}{c}\text { Intensity of tuberization } \\
\text { (yield from } 1 \text { bush in } \\
\text { grams), days after } \\
\text { germination }\end{array}$} & \multirow[t]{2}{*}{$\begin{array}{c}\text { Concentration } \\
\text { of cell sap of } \\
\text { sprouts, } \%\end{array}$} & \multirow[t]{2}{*}{$\begin{array}{c}\text { Adaptabilitycoefficien } \\
\mathbf{t}\end{array}$} \\
\hline & & & $\begin{array}{l}55^{\text {th }} \\
\text { day }\end{array}$ & $65^{\text {th }} \mathrm{da}$ & $\begin{array}{l}75^{\text {th }} \\
\text { day }\end{array}$ & & \\
\hline \multicolumn{8}{|c|}{ Earlyvarieties $(6,1-7,0 \%)$ : } \\
\hline 1 & Kuvonch-16/56 м (st.) & 72 & 362 & 425 & 471 & 6,6 & 0,86 \\
\hline 2 & Likariya (DE) & 73 & 333 & 398 & 436 & 6,9 & 0,90 \\
\hline 3 & Latona(NL) & 74 & 355 & 411 & 463 & 6,7 & 0,87 \\
\hline 4 & Karatop (DE) & 72 & 380 & 437 & 482 & 6,8 & 0,88 \\
\hline 5 & Binella (DE) & 73 & 371 & 416 & 475 & 6,8 & 0,88 \\
\hline 6 & Burren(NL) & 78 & 368 & 408 & 470 & 7,0 & 0,91 \\
\hline 7 & Red. Skarlet (NL) & 74 & 354 & 403 & 441 & 6,9 & 0,90 \\
\hline 8 & Timo (FI) & 74 & 305 & 346 & 378 & 6,7 & 0,87 \\
\hline 9 & Spunta(NL) & 75 & 376 & 431 & 484 & 6,3 & 0,82 \\
\hline 10 & Surhon-1 (UZ) & 71 & 305 & 371 & 416 & 6,7 & 0,87 \\
\hline 11 & Dolphin (BY) & 76 & 394 & 470 & 498 & 6,8 & 0,88 \\
\hline 12 & Snegir (RU) & 73 & 345 & 414 & 462 & 6,6 & 0,86 \\
\hline 13 & Antonina (RU) & 75 & 327 & 405 & 448 & 6,8 & 0,88 \\
\hline 14 & Udacha (RU) & 70 & 302 & 355 & 392 & 6,6 & 0,86 \\
\hline 15 & Rezerv (RU) & 72 & 277 & 348 & 379 & 6,5 & 0,84 \\
\hline \multicolumn{8}{|c|}{ Mid- earlyvarieties $(7,1-8,5 \%)$ : } \\
\hline 16 & Sante (NL) (st.) & 82 & 387 & 476 & 552 & 7,8 & 1,01 \\
\hline 17 & Aladin (NL) & 84 & 395 & 488 & 587 & 7,8 & 1,01 \\
\hline 18 & Romano (NL) & 86 & 352 & 440 & 519 & 8,1 & 1,05 \\
\hline 19 & Kondor (NL) & 85 & 407 & 496 & 592 & 7,8 & 1,01 \\
\hline 20 & Memphis (NL) & 84 & 375 & 462 & 543 & 7,3 & 0,95 \\
\hline 21 & Almera (NL) & 83 & 342 & 425 & 488 & 7,7 & 1,00 \\
\hline 22 & Armada (NL) & 85 & 391 & 487 & 571 & 7,8 & 1,01 \\
\hline 23 & Alvara (NL) & 84 & 393 & 490 & 580 & 7,7 & 1,00 \\
\hline 24 & Arkula (NL) & 83 & 356 & 440 & 517 & 7,8 & 1,01 \\
\hline 25 & Sylvana (NL) & 85 & 365 & 470 & 536 & 7,1 & 0,92 \\
\hline 26 & Bakhro-30 (UZ) & 84 & 401 & 495 & 572 & 7,5 & 0,97 \\
\hline 27 & Yaroqli-2010(UZ) & 85 & 417 & 510 & 595 & 7,4 & 0,96 \\
\hline 28 & Bardochli-3 (UZ) & 84 & 382 & 476 & 563 & 7,7 & 1,00 \\
\hline 29 & Ambition (NL) & 87 & 351 & 439 & 514 & 8,1 & 1,05 \\
\hline 30 & Arizona (NL) & 86 & 415 & 510 & 602 & 8,4 & 1,09 \\
\hline 31 & Kuroda (NL) & 84 & 340 & 412 & 465 & 7,3 & 0,95 \\
\hline 32 & Arsenal (NL) & 87 & 319 & 403 & 490 & 8,0 & 1,04 \\
\hline 33 & Belorossa (DE) & 85 & 335 & 461 & 519 & 7,8 & 1,01 \\
\hline 34 & Volare (NL) & 86 & 404 & 502 & 587 & 7,1 & 0,92 \\
\hline 35 & Mondial (NL) & 85 & 381 & 476 & 550 & 7,6 & 0,99 \\
\hline 36 & Picasso (NL) & 87 & 394 & 490 & 549 & 8,4 & 1,09 \\
\hline 37 & Rozara (DE) & 86 & 397 & 501 & 576 & 8,0 & 1,04 \\
\hline 38 & Saviola (NL) & 85 & 393 & 480 & 577 & 7,4 & 0,96 \\
\hline 39 & Fabula (NL) & 87 & 335 & 479 & 542 & 8,2 & 1,06 \\
\hline
\end{tabular}




\begin{tabular}{|c|c|c|c|c|c|c|c|}
\hline 40 & Floris (NL) & 84 & 319 & 444 & 527 & 7,9 & 1,03 \\
\hline 41 & Fontane (NL) & 85 & 340 & 452 & 528 & 7,6 & 0,99 \\
\hline 42 & Chempion (NL) & 86 & 351 & 470 & 545 & 7,9 & 1,03 \\
\hline 43 & Evolution (NL) & 87 & 408 & 503 & 587 & 7,8 & 1,01 \\
\hline 44 & Excellent (NL) & 84 & 316 & 424 & 508 & 7,7 & 1,00 \\
\hline 45 & Esmee (NL) & 83 & 325 & 446 & 535 & 7,6 & 0,99 \\
\hline 46 & Roko (NL) & 82 & 346 & 472 & 568 & 7,8 & 1,01 \\
\hline 47 & Arnova (NL) & 86 & 358 & 495 & 583 & 7,7 & 1,00 \\
\hline 48 & Panamera (NL) & 85 & 327 & 468 & 534 & 7,5 & 0,97 \\
\hline 49 & Amerikanski (USA) & 83 & 316 & 453 & 527 & 7,8 & 1,01 \\
\hline 50 & Pakistanski (PK) & 85 & 311 & 440 & 512 & 7,6 & 0,99 \\
\hline 51 & Neizvestno & 82 & 324 & 465 & 543 & 7,5 & 0,97 \\
\hline 52 & Sam-18 (UZ) & 84 & 345 & 501 & 570 & 7,5 & 0,97 \\
\hline 53 & Patricia (FR) & 87 & 313 & 475 & 542 & 8,0 & 1,04 \\
\hline 54 & Lucinda (NL) & 85 & 298 & 441 & 519 & 7,4 & 0,96 \\
\hline 55 & Zafira (NL) & 86 & 392 & 456 & 545 & 7,8 & 1,01 \\
\hline 56 & Lizetta (NL) & 84 & 396 & 463 & 572 & 7,8 & 1,01 \\
\hline 57 & Lena (PL) & 87 & 401 & 475 & 568 & 7,9 & 1,03 \\
\hline 58 & Arkhideya (BY) & 85 & 409 & 492 & 573 & 7,5 & 0,97 \\
\hline \multicolumn{8}{|c|}{ Mid-ripeningvarieties $(8,6-10,0 \%)$ : } \\
\hline 59 & Hamkor-11/50 (st.) & 91 & 371 & 465 & 543 & 10,0 & 1,30 \\
\hline 60 & Arinda (NL) & 94 & 347 & 451 & 528 & 8,7 & 1,13 \\
\hline 61 & Lastochka (RU) & 93 & 331 & 442 & 516 & 8,6 & 1,12 \\
\hline 62 & Talisman (BY) & 93 & 302 & 409 & 475 & 9,0 & 1,17 \\
\hline 63 & Altair (BY) & 89 & 386 & 478 & 561 & 8,7 & 1,13 \\
\hline 64 & Nakra (RU) & 93 & 355 & 460 & 534 & 8,6 & 1,12 \\
\hline 65 & Aspia (RU) & 94 & 319 & 435 & 493 & 9,4 & 1,22 \\
\hline 66 & Darga (PL) & 90 & 311 & 423 & 482 & 9,2 & 1,19 \\
\hline 67 & Sinora (NL) & 91 & 295 & 378 & 426 & 8,7 & 1,13 \\
\hline 68 & Sagitta (NL) & 92 & 303 & 387 & 435 & 8,9 & 1,16 \\
\hline 69 & Artemis (NL) & 92 & 312 & 397 & 446 & 9,4 & 1,22 \\
\hline 70 & Sineglazka(RU) & 94 & 374 & 469 & 552 & 8,6 & 1,12 \\
\hline \multicolumn{6}{|c|}{ The average concentration of cell sap according to the varieties: } & 7,7 & \\
\hline
\end{tabular}

The results of the research showed that in the potato varieties studied, the length of the vegetation period varied from 70 (Udacha) to 94 days (Arinda, Aspia, Sineglazka). Otherwise, it can be noted that among the 70 samples studied, 15 samples belong to the early groups, 43 belong to the middle-early groups, and 12 samples belong to the middle-ripening groups.

In early variety samples, vegetation period was 70-78 days, the yield of tubers from 1 bush on 55th day after germination - 277-394 g, on 65th day after germination 346-470 g, and on 75th day after germination - $378498 \mathrm{~g}$. The concentration of sprout cell sap was $6.1-7.0 \%$. The intensive rate of accumulation of tuber harvest was observed in the samples of Dolphin (394 g), Karatop (380 g), Spunta (376 g), Binella (371 g), Burren (368 g), Kuvonch-16 / 56m (362 g), Latona( $355 \mathrm{~g}$ ), Red Skarlet (354g). At the same time, the vegetative period for these samples was 72-78 days, and the concentration of sprouts cell sap was $6.3-7.0 \%$.

In medium-early variety samples, the vegetation period was 82-87 days, the harvest of tubers from 1 bush on the 55th day after germination was $298-417 \mathrm{~g}$, on the 65th day after germination - 403-510 g, on the 75th day the harvest of tubers from 1 bush was $488-602 \mathrm{~g}$, and the concentration of cell sap sprouts was in the range of $7.1-8.5 \%$. The intensive pace of crop formation of tubers from 1 bush (more than 400 grams) was obtained from the variety samples Kondor, Bakhro-30, Yarogli-2010, Arizona, Volare, Evolution, Lena and Arkhideya. In these varieties, the vegetation period is noted in 84-87 days, and the concentration of the cell sap of the seedlings is $7.1-8.4 \%$.

In mid-season potato varieties, the growing season was 89-94 days, on the 55th day after germination the harvest of tubers from 1 bush was 295-386 g, on the 65th day after germination - 378-478 $\mathrm{g}$, and on the 75th day after germination - 426-565 g. The concentration of cell sap changed 8.6-10.0\%. Intensive formation of tuber harvest from 1 bush was observed in Altair (386 g), Sineglazka (374 g), Hamkor-1150 (371 g), Arinda (347 g) varieties. At the same time, in these varieties, the vegetation period was noted in 89-94 days, and the cell sap concentration of sprouts was 8.6-10.0\%. 
As a result of determining the adaptability coefficient of potato varieties, it was found that this index was $0.82-0.91$ in early variety

samples, 0.92-1.09 in middle-early variety samples, and 1.12-1.30 in middle-aged variety samples.

\section{CONCLUSION}

Thus, in determining (evaluating) potato variety samples for early ripeness, the main indicator is the cell sap concentration of tuber sprouts. As a result of determining the cell sap concentration of tuber sprouts using the Rosket Pal-1 electronic refractometer using the accelerated field method, it was found that the cell sap concentration of sprouts in early variety samples was $6.1-7.0 \%$, in medium non-early samples $-7,1-8.5 \%$, for mid-season samples - 8.6-10.0\%, and for late unripe variety samples $-10.1 \%$ and more. The accuracy of this method was confirmed by the length of the vegetation period and the intensity of accumulation of the crop of tubers of the studied variety samples. It is proved that between these methods there is a direct correlation. At the same time, the coefficient of adaptability in early variety samples was $0.8-0.9$, in middle-early variety samples $-1.0-1.1$, and in middle-aged variety samples $-1.1-1.3$. According to the results of the research, applications for the agency of intellectual property of the Republic of Uzbekistan were submitted.

\section{REFERENCES}

[1] Methods of research on potato culture (All-Russian Scientific Research Institute of Potato Farming) .- M .: 1967.-p.210

[2] Batsanov N.S. Potatoes.- M .: 1970. -p.376.

[3] Pisarev B.A. The book about the potato.- M .: 1977.-p.232.

[4] Dospekhov B.A. Methodology of field experience. M.: 1985.-p.351

[5] Ostonakulov T.E. Adaptation coefficient and crop capacity of tuberous potato varieties grown as early and double crops .The South Asian Academic Research Journals. Vol 7, Issue 11, November 2017.p.5-10.

[6] Astanakulov T.E. The technology of cultivation, selection and seed farming of potatoes in the Zarafshan Valley. - Samarkand, 2018. - p.188.

[7] Ostonakulov T.E., Zuev V.I., KodirkhuzhaevO.K. Fruit-growing-vegetable growing (Vegetable-growing) .- T $\therefore$ Navruz, 2018.-p.552.

[8] http://www.saarj.com 